\title{
Neither Full nor Flat: Women, Representation, and Politics in Walter Scott's Rob Roy
}

Bronte Wells

Scott's Rob Roy is a novel that comments on the contemporary politics of its publication, as well as the issues of the past. Just as Scott's novel is commenting on the political emotions of the age of revolution, Rob Roy, intentionally or unintentionally, allows for the readers to analyze aspects of Romantic gender politics through the novel's female characters and how they are framed in the plot.

Though there are few female characters amongst the cast in Scott's Rob Roy, Diana Vernon and Helen MacGregor are two of the more memorable. Both women are dynamic, exciting, and their bold actions and thoughts are enticing to readers. However, they still suffer from similar trappings that other female characters in literature have fallen into and, while they appear and feel dynamic, the characters are also flat. Female bodies and characteristics have been repetitively used for the purposes of allegory or metaphor; women as characters are not simply women, but are embodiments of fear, ridicule, ideals, and a whole host of politics. While Helen and Diana are not fully allegorical characters, there are politics and fears that they are meant to represent and that prevents them from fully actualized human characters within Rob Roy. Helen MacGregor is arguably the most threatening character in the novel. She is not painted as a character to be reviled; however, she is meant to be feared and be read as such by the audience. While her husband plays the role of Robin Hood-reborn, Helen plays the wronged, merciless, and violent revolutionary. Helen's transgressive characteristics are more for the benefit of depicting a set of politics and allowing Rob Roy to be a comparatively less, complicated hero than imagining Helen MacGregor as a fully realized character; for Scott, imbuing Helen with masculine qualities allows for him to represent the dangerous aspects of revolution in her, instead of his title character. Romantic characters are always moving through texts that are concerned with contemporary politics; however, female characters and bodies are traditional sites of allegory and thus, tend to be the characters that are more wholly symbolic of political discourse, and their transgressive attributes are the markers of cultural politics of their contemporary era. 
The dates for the Romantic period are uncertain. Earlier academics placed the beginning of the Romantic period in 1798 with the publication of Coleridge and Wordworth's collection of poems, Lyrical Ballads, and then places the end in the 1830's when the main canon authors began to die or change in their literary structuring. For the purpose of this paper, Duncan Wu's suggested dates of 1770, before the American Revolution began, to 1850, which he claims the end because of the closing of the age of European Revolutions will function as place holder dates. ${ }^{1}$ In any case, the Romantics stood at the crossroads of the early modern and modern periods in Europe's history. Earlier events, such as the American Revolution (1775-1783) and the Jacobites Rebellions of Scotland $(1715,1745)$, impacted the Romantics as influences, but it is the events contemporary to the canon writers, which includes Sir Walter Scott, Byron, Shelley, Wollstonecraft, Coleridge, Wordsworth, etc., that would be of significant influence. The French Revolution (1789-1794) and the Reign of Napoleon, as well as the Napoleonic wars, were the events which had the greatest immediate impact. The impact would be so great that the writers and scholars of the era "recognized... [the events] as unprecedented in their magnitude." 2 David Simpson elaborates that how the public viewed historical events had a way of shaping why the events would appeal to the Romantics. He states that the English "felt the American colonists had backed into a revolution, or had been pushed into it, where as the French Revolution appeared to be the planned implementation of radical and coherent principles," which were based on "metaphysical principles and philosophical materialism" instead of more "concrete, and less abstract, structures. ${ }^{3}$ It is the emotions of the era and the radical politics that would influence the Romantics. However, the Romantics were not cohesive in their responses. Some Romantics, like Wordsworth and Shelley, were enthusiastic supporters, others, like Sir Walter Scott, were more reserved. Romantics spanned the political spectrum, which makes it difficult to track direct political influence. In the case of understanding the influences of Romanticism in this particular paper, it is enough that audience is aware of the time era and when major events happened, rather then a survey of the political events of the French Revolution. However, in understanding Scott, a survey of the Jacobite Rebellions of Scotland, which occur well before the Romantic period, will be necessary.

The Act of Union was signed in 1707, joining Scotland, England and Wales into a single nation: Great Britain. It is through this union that British identity was formed, but

\footnotetext{
${ }^{1}$ Duncan Wu, ed, Romanticism: An Anthology, 4th editon (Oxford, UK: Wiley-Blackwell publishers ltd., 2012): xxxii-iii.

2 James Chandler, “Introduction," in The Cambridge History of English Romantic Literature, ed. James Chandler (Cambridge, UK: Cambridge University Press, 2009), 2.

3 David Simpson, "France, Germany, America," in The Cambridge History of English Romantic Literature, ed. James Chandler (Cambridge, UK: Cambridge University Press, 2009), 209.
} 
also resisted. Following the Act of Union, Scottish nationalism began to grow and along with this growth came violent clashes between Scottish Jacobite rebel and the English colonial army. The first major rebellion was in 1715 . The 1715 rebellion comes at the heels of the 'Glorious Revolution' and the taking of throne by William of Orange. William of Orange, though outside of the Romantic timeline, aggravated later situations through his authorization of the murder of Scottish clan members, which only served to encourage the growth and spread of Scottish nationalism. ${ }^{4}$ The rebellion broke out after the death of William and Anne, when the crown was passed to Anne's cousin, George I, which gave the Jacobites a window of opportunity to attempt to seize the throne and reinstate the Stuarts through James II's son, James. ${ }^{5}$ The 1715 rebellion was less successful than the 1745, and achieved relatively few Jacobite goals. Following the end of the rebellion, England cracked down on Scotland and used what Daniel Szechi names as 'deterrence' and 'exemplary punishment. ${ }^{6}$ Any person who was known to have taken arms for or had supported the Jacobites could face: "hanging, drawing, and quartering for themselves personally, forfeiture of all their property and concomitant destitution for their families." Some measures were designed to suppress the Highlander and Catholic minorities, who were perceived to be the groups to fear. The second major conflict arrived in 1745 with the return of Charles Edward Stuart. The 1745 conflict was the result of Charles Edward Stuart, grandson of James II, attempting to reclaim what he saw as his rightful claim to the throne of Britain and seize power from the current king of Britain, George II. $^{8}$ Charles Edward Stuart gathered a significant portion of his early forces amongst the Highlanders, and even though they would be out numbered by other groups, the Highlanders remained the most visible, which made them the focus of the English government. ${ }^{9}$ Geoffrey Plank describes that government soldiers tended to enact vindictive violence against the population. $\mathrm{He}$ describes one instance where the death of one English soldier resulted in the burning and destroying of houses in a near by community; these actions were described by the English army as to be controlling "disaffected" Highlander communities. Following the end of the rebellion, the English army raided Jacobite homes destroying the building and seizing property. Ultimately, there would be an expansion of military actions and laws that were designed to suppress Highland culture, which became a rallying point for Scottish nationalists and Romantic writers.

\footnotetext{
${ }^{4}$ Merry E. Wiesner-Hanks, Early Modern Europe: 1450-1789 (Cambridge, UK: Cambridge University Press, 201), 343.

${ }^{5}$ Ibid., 343.

${ }^{6}$ Daniel Szechi, 1715: The Great Jacobite Rebellion (New Haven: Yale University Press, 2006) 199.

${ }^{7}$ Ibid., 199.

${ }^{8}$ Geoffrey Plank, Rebellion and Savagery (Philadelphia: University of Pennsylvania Press, 2006$) 1$.

${ }^{9}$ Ibid., 53.
} 
Transgressive is defined in a variety ways: "passing beyond some limit, violates or challenges social, moral, or artistic conventions; subversive, experimental." ${ }^{10}$ Helen MacGregor can be certainly counted as a transgressive character, since transgressive characters pass over boundaries and are fluid instead of remaining in one particular category. The Romantics used them regularly in their works to communicate complex thought, ideas, and politics. These characters are able to transgress the contemporary politics of the 18th and 19th centuries and present progressive, revolutionary politics that Romantics either pushed for or were, at least, sympathetic to. Transgressive characters have an element of irrationality that fits into the Romantics preoccupation with the irrational, which factored into their aesthetics; characters are inhabited with contradictory elements, like the masculine and the feminine, which present as mysterious, confusing and almost mirrors aspects of the sublime. In order for transgression to exist, there must be boundaries for characters to cross; for the Romantics, the social and political boundaries were the primary concern for critique and revolutionary thought. Transgressive characters allow for Romantic authors to create figures that can stand in for a variety of political, social, and cultural ideas, while having the characters physically trespass over boundaries of the 'normal' in the framework of novel and the laws that govern the world of the novel.

The female characters of Rob Roy were not created in a vacuum; the transgressive positions they hold in the novel were informed by the historical events and culture of the Romantic era. Women's history of the 18th and 19th centuries is complicated. Though women participated in political activism and revolutionary activities as men did, their image as revolutionaries was compromised, even as events were developing. Neil Hertz recounts a cartoon, that was included in Burke's Reflections, as having female figures that Burke described as "the furies of hell, in the absurd shapes of the vilest of women." ${ }^{11}$ Hertz' essay focuses on the continuation of using images of horrific women in the political and cultural discourse of the Revolution of 1848, but he does note that the images of revolutionary women being described as"hideous and fierce but not exactly sexless" existed in the previous revolutions of Western Europe. ${ }^{12}$ It suggests that the height of female monster-hood is rooted in sexuality, if it is deemed inappropriate or unrestrained. However, that leaves questions about how women were depicted if an 'unrestrained sexuality' is not a factor in her portrayal or character: what if they transgress some boundaries, but not those that govern sexuality? Can a woman still be pictured as a threat if she has some ties to traditional female roles? Revolutionary Women were, more often then not, portrayed as hysterical or monstrous.

\footnotetext{
10 “Transgressive." OED.

${ }^{11}$ Neil Hertz, “Medusa’s Head: Male Hysteria under Political Pressure,” Representations 40 (1983): 27.

12 Ibid., 27
} 
In some cases their monstrosity was linked to being, as one poem cited by Vivian Jones states, "unsex'd."13

The status of being 'unsex'd' imagines revolutionary or rebellious women as outside the gender binary, which signaled them as a threat. Scholars have suggested that gender roles became embroiled in national identity and patriotism, which further complicates matters. Jones cites that women's gender performance in England was a tool used to define women's "'softer charms' and 'modest virtue' of sensibility" as appropriate behavior and "proof of patriotism." "Jones connects the construction of the patriotic feminine to the strength of the nation. Jones states that a variety of conservative writers, men and women, focused on female gender construction as a check point for measuring "national maturity and corruption." 15 Jones suggests that female revolutionary theorists wrestled with the very conundrum they were placed in. Jones notes that in a variety for revolutionary women's writing, such as Wollstonecraft, the praise for revolutionary politics, while also having a tone of "longing for respectability, created a moment where one can identify "active, anti-nationalistic femininity is threatened with regulation. ${ }^{16}$ Jones suggests that while the women aimed to create a new "subject position" for themselves, the "repressive binary" that they actively work against was a difficult to overcome, particularly because national identity and gender construction had become so intertwined. ${ }^{17}$ Women are put in the precarious position as unmoving, political objects by virtue of their nature, while being held responsible for the morality of the nation, despite having little to no agency. In consideration with Rob Roy and Helen MacGregor, this understanding complicates her as a character and how the audience is lead to read her. Helen has particular ties to areas traditionally kept in the arena of women and these are the areas that are put at odds to contradict other qualities.

Helen MacGregor is a fearsome woman that is allied with a variety of traits that would have been coded as masculine at the time of publishing. However, the descriptions that code her as female are just as striking. Her feminine qualities are thrown in sharp contrast with her masculine qualities and create a unique character that is a symbol for multiple viewings of the politics she is meant in embody. Helen is introduced to the novel through her relationship to Rob Roy; the readers are told by the bailie that she is "Helen Campbell, Rob's wife." 18 The emphasis and how early this information is provided ties Helen's identity to her role as wife to Rob Roy and some of the aspects of traditional gender roles. Scott scripts Helen's speech into one that is not avoiding

\footnotetext{
${ }^{13}$ Vivien Jones, "Femininity, Nationalism And Romanticism: The Politics of Gender in the Revolution Controvers," History of European Ideas 16, no.1-3 (1993): 299.

${ }^{14}$ Ibid., 299.

${ }^{15}$ Ibid., 301.

${ }^{16}$ Ibid., 304.

${ }^{17}$ Ibid., 305.

${ }^{18}$ Sir Walter Scott, Rob Roy (Oxford: Oxford University Press, 2008), 349.
} 
politics, but is concerned with hearth, home, and food, instead of abstract concepts. Helen states multiple times that her primary concern and reasons for her rage are that her and her people have been left with "neither house nor hold, blanket nor bedding, cattle to feed us, or flocks to clothe us" and that "the very name of our ancestors have...been taken away." ${ }^{19}$ Helen, in voicing the main points of her grievances, is tied to some form of femininity. She is tied to family and land; the concerns she has are primarily local and of the material realities of survival for people. Helen's feminine qualities code her as non-threatening, but only to certain groups. Helen is cast a protector and warrior for her highland people, her family, and Scots who are oppressed by the English. Helen's role as a woman, wife, protector, and a figure of concern for her native Scotland brings forth a different form of nationalism. Her Femininity is almost a confirmation of her identity as a Scottish person because it ties her Scottish heritage, family, and land. Similar to the writers Jones covers, both Romantic and Conservative, Scott links gender to some form of national belonging. Scott uses Helen's feminine qualities to cast her a sympathetic figure and one that is tied to a particular national identity. Her feminine qualities makes her sympathetic to those who have suffered as she has, which functions differently than her masculine qualities.

Women are a fairly common character that may pose as the 'other' in a text. David Simpson, summarizing Leslie Fiedler, states that woman are "an unassimilated, perhaps forever unassimilable, stranger, the first other of which the makers of our myths, male as far back as reliable memory runs, ever became aware." ${ }^{20}$ Simpson elaborates that a woman is made stranger and further othered if she "foreign or uncanny by birth or origin." ${ }^{21}$ For Simpson, an othered or strange woman is the field in which male fears of powerlessness are cast onto women who, then, become figures of fear. For a nonScottish audience, Helen MacGregor is already cast the role of a strange woman. She carries with her a nation and a culture that would be foreign to an English audience, and is made even more strange by her connection to the Scottish highlanders, which is portrayed as foreign against even southern Scottish culture. Scott confirms her alien status to the English through selecting scottish gaelic words, like "Sassenachs,"which highlights the cultural differences and gives her a language that is noticeably different. Helen's foreignness to the English and her gender set her as threat. She is a stranger, but it is not just her status as a possibly threatening stranger that makes her a person to be feared. Helen MacGregor is a transgressive characters; she blurs the lines between the masculine and the feminine, which, in the historical and cultural context of the Romantic period, coded her a threatening figure.

\footnotetext{
${ }^{19}$ Ibid., 349.

${ }^{20}$ David Simpson, "Strange Women" in Romanticism and the Question of the Stranger (Chicago: The University of Chicago Press, 2013), 209.

${ }^{21}$ Ibid., 209.
} 
Helen MacGregor is a woman who carries masculine and feminine traits, which are employed in different ways that interact with Scott's interests in nationhood. Women inhabiting qualities that are perceived or constructed as masculine is a concept/reality that is neither new nor modern. However, as Kathleen Wilson notes in her article, "female masculinity" or "masculine values" that were not the "product of male bodies" was part of the cultural and political anxieties of the late 18 th and early 19 th centuries. ${ }^{22}$ Wilson defines "female masculinity as "an enactment of masculine value by female bodies surprised by its ability to destabilize binary gender systems in many different locations." 23 Wilson argues that female masculinity marked "out a domain in which women became primary actors of masculine principles, and such women...not only usurped male prerogatives but also successfully performed attributes long considered essential to patriotic virtue." 24 Wilson connects female masculinity with British nationalism, identity, and patriotism. Though women were often supporters of British identity, they were often pictured as threats by male British politicians and commentators; the masculine woman was seen and treated as a threat to the "British nation's survival." 25 Wilson states that "female masculinity became the target of surveillance" and that the women were often charged with "immorality." 26 With consideration to the historical context, Helen MacGregor status as a character is far more complicated. Helen's feminine traits shape her into a woman of Scotland, a member of a nation; however, it is her status as a character possessing a female masculinity that makes her a direct threat to British identity and social cohesion.

Helen MacGregor passes over the boundaries of male and female; it is her "female masculinity" that makes her a threat to British characters, particularly male figures, in the novel. If Scott's Rob Roy had been more fantastical and Helen transformed into a man, like a variety of other myths and texts, she would probably not be as feared. The fear that Helen produces does not rest with her martial power or her violence, she is feared because she has a masculinity that is divorced from a male body; it is the female body possessing masculine attributes that is meant to be coded as terrifying, threatening, and dangerous. Upon the second meeting with Helen MacGregor, Frank describes her as having "specks of blood on her brow, her hands, and naked arms, as well as on the blade of the sword which she continued to hold in her hand." ${ }^{27}$ Frank continues to focus the martial attributes of Helen, commenting that "her keen black eyes and features expressed an imagination inflamed by the pride of gratified revenge, and the triumph of

\footnotetext{
${ }^{22}$ Kathleen Wilson, "Nelson's Women: Female Masculinity and Body Politics in the French and Napoleonic Wars," European History Quarterly 37, no.4 (2007): 563.

${ }^{23}$ Ibid., 565.

${ }^{24}$ Ibid., 565.

${ }^{25}$ Ibid., 567.

${ }^{26}$ Ibid., 566.

${ }^{27}$ Scott, 357.
} 
victory. ${ }^{28}$ Despite the fact that women have participated in war as men have, war and martial abilities are culturally coded as masculine. Wilson states that women who participated in war, whether through political activism or, in rare case, fighting at the front, were included in the 'female masculinity' framework because they were transgressing into the realm of the masculine. Helen MacGregor participates in fighting, however, the emphasis should be on the blood that she is described to have on her. Rob Roy fights and engages in battle, yet, the same focus of Helen's blood splatter is not brought to any blood splatter he may have on his person. With blood splatter visibly on her, Helen is far more fearsome and threatening. She not only fights, but she wears the aftermath. Helen MacGregor's appearance is described in masculine terms as well. Frank describes Helen as having "a masculine cast of beauty" and that "she wore her plaid, not drawn around her head and shoulders, as is the fashion of the women...but disposed of around her body as the highland soldier wear their's." ${ }^{29}$ Through her allegiance to traditionally masculine realms and her appearance being largely related to masculine beauty, Helen MacGregor is staged as a transgressive character that is meant to fulfill multiple roles: as a Scottish woman who is sympathetic because of her suffering to those loyal to the Scottish cause and as a threatening, strange woman to those rallying around British identity.

What is the importance of a transgressive character like Helen MacGregor? How does she function in the plot of the novel? Helen works to be a more threatening form of her husband. She is able to be brutal and harsh because Rob Roy, in order to be favorable viewed by all readers, needs to be the Robin Hood character. Her transgressive nature as a woman lends to being that threat. The contrast between her and her husband may be due to Scott attempting to represent as many experiences of the revolutions and revolutionaries. Helen is representing an aggressive Scottish nationalism that is fueled by righteous anger; through Helen, Scott is able to explore the extremes in rage of revolutions, but still keep his title character as someone who is completely sympathetic to the reader, with far less complications than Helen. Though Beshero-Bondar's chapter on Scott is in connection with his work on the Ossian Tales, her suggestion is that Scott's work was partially influenced by his negotiations of having the "the enthusastic support" from "English literary authorities," in order to work towards preserving "the cultural distinctivenss of Scotland" may apply to how Scott presented Scottish nationalism. ${ }^{30}$ His own desires to support the United Kingdom, while have sympathies for the Scottish national cause must not dismissed. If the nationalism of Rob Roy is made separate from the nationalism represented by his wife, then it allows Scott to

\footnotetext{
${ }^{28}$ Ibid., 357.

${ }^{29}$ Ibid., 347.

${ }^{30}$ Beshero-Bondar, "Scott's Romantic Epics and the Ossianic Politics of Scottish Nationalism," Women, Epic, and Transition in British Romanticism (University of Delaware Press, 2011): 75.
} 
negotiate Scottishness and revolution without the struggle of making one character both Robin Hood and the brutal revolutionary.

Representation of women is a vastly complex topic in any study of literature. To fully understand how women are represented and what is the function of that representation in Rob Roy, or any Romantic text, one must understand the cultural history of female representation during the age of Revolution. The transgressive qualities of Helen MacGregor are not there just for the sake of character construction, they are there to communicate and interact with the politics that Walter Scott was living and participating in. 
Bibliography

Beshero-Bondar. "Scott's Romantic Epics and the Ossianic Politics of Scottish Nationalism." Women, Epic, and Transition in British Romanticism. pp.73-84. University of Delaware Press, 2011.

Chandler, James. "Introduction." In The Cambridge History of English Romantic Literature, edited by James Chandler, 1-18. Cambridge, UK: Cambridge University Press, 2009.

Hertz, Neil. “Medusa's Head: Male Hysteria under Political Pressure.” Representations 40 (1983): pp. 27-54.

Jones, Vivien. "Femininity, Nationalism And Romanticism: The Politics of Gender in the Revolution Controversy." History of European Ideas 16, no.1-3 (1993): pp. 297-305.

Plank, Geoffery. Rebellion and Savagery. Philadelphia: University of Pennsylvania Press, 2006.

Scott, Walter. Rob Roy. Oxford: Oxford University Press, 2008.

Simpson, David. "Strange Women." Romanticism and the Question of the Stranger. pp. 209-248. Chicago: The University of Chicago Press, 2013.

Simpson, David. "France, Germany, America." In The Cambridge History of English Romantic Literature, edited by James Chandler, 204-223. Cambridge, UK: Cambridge University Press, 2009.

Szechi, Daniel. 1715: The Great Jacobite Rebellion. New Haven: Yale University Press, 2006.

Wilson, Kathleen. "Nelson's Women: Female Masculinity and Body Politics in the French and Napoleonic Wars.” European History Quarterly 37, no.4 (2007): pp. 562-581.

Wiesner-Hanks, Merry E. Early Modern Europe: 1450-1789. Cambridge, UK: Cambridge University Press, 2013.

Wu, Duncan, ed. Romanticism: An Anthology, 4th editon. Oxford, UK: Wiley-Blackwell publishers ltd., 2012. 